\title{
KEARIFAN LOKAL DALAM PEMBENTUKAN LANSEKAP BUDAYA PADA PERMUKIMAN LAHAN BASAH DI KOTA PALEMBANG
}

\author{
Tutur Lussetyowati \\ Program Studi Teknik Arsitektur Fakultas Teknik Universitas Sriwijaya \\ Jl. Palembang - Prabumulih KM.32 Kabupaten Ogan Ilir, Sumatera Selatan \\ *Email: tutur_lus@yahoo.co.id
}

\begin{abstract}
ABSTRAK
Lanskap budaya merupakan hasil dari proses sejarah yang kompleks (Rapoport, 1992). Pembentukan pola permukiman di lahan basah merupakan salah satu hasil lansekap budaya. Kondisi fisik alamiah Palembang sebagian besar terdiri dari rawa dan sisanya berupa darat, sehingga banyak permukiman yang terletak di daerah lahan basah ini. Permukiman di lahan basah mempunyai karakteristik yang unik yang berbeda dengan permukiman di daratan kering. Pengaruh kondisi alam yang berupa lahan basah sangat terlihat pada bentukan pola permukimannya. Dalam kurun waktu yang lama penduduk lokal sudah mempunyai cara untuk mengatasi kendala lingkungan fisiknya dalam membangun permukimannya. Tujuan penelitian ini adalah untuk mendapatkan gambaran tentang kondisi permukiman di daerah rawa yang dikaitkan dengan kearifan lokal penduduk dalam mengatasi keterbatasan alam (lahan babsah). Metode yang digunakan adalah studi kasus, melalui tahapan survey lapangan dan analisa terhadap hasil survey. Analisa yabg digunakan adalah analisa deskriptif terhadap hasil survey lapangan. Dari hasil penelitian didapatkan bahwa permukiman di atas rawa mempunyai karakteristik yang unik karena sebagian besar aktifitas penduduknya dilakukan di atas air. Dengan kondisi yang demikian maka perilaku penduduknya akan terpengaruh dan menyesuaikan dengan kondisi lingkungannya. Pola-pola perkembangan permukimannya juga mempunyai ciri khas tersendiri, karena merupakan perkampungan yang tumbuh secara alamiah tanpa mengadakan perubahan yang berarti pada lingkungan alamnya. Pola permukiman yang demikian ini menunjukkan kearifan lokal penduduk dalam mengelola lahan basah tanpa menyebabkan gangguan terhadap lingkungan alam.
\end{abstract}

Kata Kunci: permukiman, lahan basah, kearifan lokal, lansekap budaya.

\section{PENDAHULUAN}

Permukiman merupakan salah satu hasil lanskap budaya. Lanskap budaya merupakan hasil dari proses sejarah yang kompleks (Rapoport, 1992). Lanskap budaya dihasilkan dari interaksi jangka panjang antara berbagai karakteristik budaya dari populasi dan kelompok yang berbeda dengan kondisi alam yang bervariasi secara fisik dan ekologi menghasilkan berbagai variasi yang komplek dari material budaya. Permukiman di daerah rawa di Palembang merupakan salah satu hasil dari proses tersebut.

Kota Palembang secara administrasi merupakan ibukota Propinsi Sumatera Selatan. Kota ini sejak berdirinya terletak di tepian Sungai Musi yang sangat lebar dan bisa dilayari kapal-kapal besar. Beberapa sungai yang lebih kecil juga banyak terdapat di kota ini. Dengan potensi fisik yang demikian maka kota
Palembang mempunyai karakter sebagai kota air.

Kota Palembang sebagian besar terdiri dari rawa dan sisanya berupa darat. Pada awalnya permukiman penduduk berada di tepian jalur transportasi utama yaitu sungai. Bentuk rumah-rumah di sini berupa rumah panggung atau rumah rakit yang mengkuti ketinggian pasang surut air. Bentuk rumah panggung ini sangat sesuai untuk daerah yang terpengaruh oleh pasang surut air.

Pada daerah rawa, terutama di tepian sungai, rumah-rumah yang tumbuh berikutnya masih menggunakan bentuk rumah panggung, sebagai antisipasi terhadap pasang surut air. Rumah-rumah ini dihubungkan dengan jalur jalan di atas air yang disebut 'jerambah'. Perkembangan permukiman seperti ini sangat cepat dan kemudian banyak memenuhi daerahdaerah rawa dan cenderung berubah menjadi kumuh. Perkembangan yang cepat ini juga 
disebabkan makin banyaknya pendatang dari sekitar Palembang.

Menurut Habraken sebagai suatu produk komunitas, bentuk lingkungan permukiman merupakan hasil kesepakatan sosial, bukan merupakan produk orang per orang (Antariksa, 2011). Artinya komunitas yang berbeda tentunya memiliki ciri permukiman yang berbeda pula. Suatu rumah dirancang dan suatu permukiman di tata menggambarkan hubungan antara individu, keluarga dan komunitasnya yang tentu saja bergantung pada masing-masing budaya. Konsekuensinya adalah organisasi ruang dirumah, tatanan permukiman dan akses ke fasilitas umum dipengaruhi oleh pandangan hidup komunitas tesebut.

Pada permukiman di lahan basah di tepian sungai, kondisi fisik alam juga mempengaruhi bentukan pola permukimannya. Keterbatasan lahan yang kering, memberi pengaruh pada bentukan lingkungan permukiman, yang merupakan manifestasi dari pola hubungan antara budaya masyarakat penghuni dan lingkungan alamnya. penulis untuk korespondensi. Jika penulis lebih dari satu orang dan bekerja di lembaga yang sama, maka pencantuman satu alamat telah dianggap cukup mewakili alamat penulis lainnya.

\section{METODE PENELITIAN}

Metode yang dilakukan dalam penelitian ini adalah metode case study (Yin, 2014) yang terdiri dari pengamatan secara umum pada permukiman di lahan basah yang ada di Palembang untuk kemudian ditentukan daerah yang akan menjadi fokus penelitian secara detail. Berdasarkan hasil pengamatan awal, maka fokus kajian adalah pada permukiman lahan basah yang terletak di tepian sungai Musi, dengan pertimbangan pengaruh pasang surut air masih berpengaruh pada kawasan tersebut. Lokasi terpilih adalah Kelurahan 3-4 Ulu dan Kelurahan 5 Ulu. Untuk selanjutnya dilakukan survey lapangan dan wawancara dengan penduduk setempat. Wawancara dilakukan dengan 10 responden, yang dianggap mewakili kawasan permukiman. Sedangkan survey lapangan meliputi survey terhadap pola permukiman, tipologi bangunan, tata masa bangunan, sirkulasi dan ruang terbuka sebagai elemen-elemen yang paling berpengaruh dalam pembentukan lanskap budaya kawasan permukiman. Analisis yang digunakan adalah analisis deskriptif kualitatif dengan menggunakan pendekatan matriks hubungan antara kegiatan dan perilaku penghuni dengan ruang-ruang yang ada di kawasan permukiman tersebut. Analisis ini juga menggunakan teknik super impose dengan peta-peta.

\section{HASIL DAN PEMBAHASAN}

\section{Tinjauan Pemukiman Lahan Basah dalam Konteks Kota Palembang \\ Pada awalnya wilayah Kota Palembang} sebagian besar merupakan daerah rawa. Secara umum daerah rawa-rawa di Palembang bisa dibagi menjadi tiga jenis, yaitu: (1) Rawa yang dalam dan terus menerus berair; (2) Rawa sedang, yang pada saat pasang terendam dan saat surut agak becek; dan (3) Rawa yang dangkal.

Pada awalnya permukiman di Palembang biasanya berbentuk rumah panggung dan berada di tepian sungai sebagai orientasi. Pada saat Belanda datang dan mulai membangun permukiman, mereka cenderung memilih daerah darat sebagai daerah terbangun disertai dengan pembangunan kolam-kolam retensi untuk penampungan air (drainase) Hal itu sudah mereka perhitungkan terhadap kondisi tanah yang kurang bisa menyerap air.

Pada perkembangannya, seiring dengan pesatnya perkembangan kota Palembang, mulai terasa kebutuhan akan lahan untuk bangunan (permukiman dan fasilitas kota lainnya). Hal ini juga dipicu oleh perubahan prasarana transportasi dari sungai ke jalan (darat). Beberapa daerah rawa mulai ditimbun (terutama di tengah kota) dan dijadikan areal darat untuk dibangun. Penimbunan ini sering tidak memperhitungkan persyaratan teknis untuk reklamasi rawa, akibatnya timbul dampak pada daerah-daerah yang semula rawa, seperti terjadinya genangan air pada saat musim hujan dan terjadinya banjir pada kawasan-kawasan tertentu.

Kawasan permukiman yang masih mempertahankan rawa sebagai lahan tempat berdirinya rumah/bangunan makin berkurang dan hanya terdapat di beberapa kawasan terutama di tepian sungai di mana pengaruh pasang surut air masih sangat terasa. Permukiman daerah rawa pada tepian sungai ini masih sangat penting untuk dipertahankan dengan bentuk semula, mengingat penimbunan rawa yang tidak mengikuti aturan bisa 
menimbulkan dampak yang cukup serius bagi kota Palembang.

Pengembangan daerah rawa dengan cara reklamasi seperti yang sudah dilakukan perlu direncanakan secara skala makro (skala kota), karena dampak aliran air bisa mengakibatkan banjir. Oleh karena itu perlu dilakukan perencanaan kota dengan tetap mempertahankan keberadaan rawa.

\section{Lanskap Budaya pada Permukiman di Lahan Basah}

Lanskap budaya adalah suatu area geografis, termasuk sumberdaya budaya dan natural, dan kehidupan di atasnya, yang dikaitkan dengan peristiwa bersejarah, kegiatan aatau orang yang membentuk budaya atau nilai estetis. Ada empat tipe lanskap budaya yaitu: situs sejarah, disain lanskap bersejarah, lanskap vernacular, dan lanskap etnografis. Dalam penelitian ini telrihat bahwa kawasan permukiman ini merupakan lanskap vernacular.

Lanskap vernacular adalah lanskap dimana penggunaan, konstruksi atau lay out fisiknya mencerminkan tradisi, perilaku sosial dan kegiatan individu dalam jangka panjang, yang melambangkan bentukan fisik dan material dan hungunan di antaranya, termasuk pola organisasi ruang, penggunaan ruang, sirkulasi, vegetasi, dan struktur (Page, 1998). Lanskap vernacular juga merupakan lanskap dimana bentukan fisik, biologis dan budaya merefleksikan kehidupan sehari-hari penduduk lokal.

Bentukan lanskap kota merupakan hasil dari berbagai faktor yang membentuknya. Terdapat hubungan antara budaya, sistem kearifan lokal dan pembangunan berkelanjutan, sehingga merupakan hal yang penting untuk memperhatikan keterkaitan antara budaya lokal dan pembangunan berkelanjutan.

Rapoport (1992) juga menyatakan bahwa budaya sebagai suatu kompleks gagasan dan pikiran manusia bersifat tidak terjaga. Kebudayaan ini akan terwujud melalui pandangan hidup (world view), tata nilai (values), gaya hidup (life style), dan akhirnya aktifitas (activities) yang bersifat konkrit (Antariksa, 2011). Selain itu Rapoport juga mengemukakan bahwa permukiman tradisional merupakan manifestasi dari nilai sosial budaya masyarakat yang erat kaitannya dengan nilai sosial budaya penghuninya, yang dalam proses penyusunannya menggunakan dasar normanorma tradisi.
Terbentuknya sebuah permukiman dipengaruhi oleh beberapa faktor yang secara keseluruhan dapat dilihat unsur-unsur ekistiknya. Adapun unsur-unsur ekistik pada sebuah pola permukiman meliputi natural, manusia, sosial, pernaungan dan jaringan (Doxiadis, 1968). Kelima elemen ekistik tersebut membentuk lingkungan permukiman. Permukiman tepian sungai merupakan salah satu bentuk keterkaitan antara elemen-elemen ekistik tersebut.

Dilihat dari asal etnis penduduk yang tinggal di kawasan tersebut sebagian besar penduduk berasal dari daerah sekitar kota Palembang, seperti dari Ogan Komering Ilir, Ogan Komering Ulu, Musi rawas, Musi Banyuasin dan dari Palembang sendiri, yang termasuk dalam Suku Melayu. Selain itu terdapat juga penduduk yang berasal dari Jawa dan keturunan Cina serta Arab. Penduduk yang tinggal di atas lahan basah adalah penduduk yang berasal dari permukiman yang mempunyai karakteristik alam yang sama yaitu daerah rawa, sehingga bentukan permukiman merupakan hasil dari kondisi budaya penduduk pendatang tersebut. Pada kenyataannya mereka bisa langsung menyesuaikan dengan kondisi permukiman dan kondisi alamnya.

Mata Pencaharian penduduk sebagian besar terkait dengan keberadaan sungai sebagai sumber mata pencaharianya seperti nelayan, pedagang di tepi sungai, tukang perahu, dll. Hal ini juga berkaitan dengan pemilihan tempat bermukim di tepian sungai besar (Sungai Musi). Di samping itu juga terdapat beberapa fasilitas yang mendukung pekerjaan mereka, yaitu adanya dermaga-dermaga di depan setiap unit lingkungan permukimannya. Dermaga ini juga berfungsi untuk melayani transportasi penduduk melalui sungai.

Pada kondisi tertentu terlihat bahwa permukiman di daerah rawa di tepian sungai ini hanyalah bersifat transisi, artinya penduduk yang mempunyai kemampuan lebih tinggi akan pindah ke daerah lain (karena alasan kenyaman dan kelengkapan fasilitas). Tetapi melihat lama tinggal penduduk di daerah tersebut, bisa diartikan bahwa walaupun hanya bersifat transisi, permukiman daerah rawa akan bertahan untuk waktu yang cukup lama. Karena begitu ada penduduk yang keluar, akan ada lagi yang memasuki kawasan permukiman tersebut. Melihat kondisi tersebut ternyata bahwa penataan kawasan permukiman daerah rawa 
masih diperlukan untuk meningkatkan kualitas lingkungan tersebut.

\section{Pola Permukiman}

Menurut Dahlian (2012) pola tapak permukiman di tepian sungai dibedakan menjadi dua kawasan, yaitu: (1) Tapak permukiman yang berada di tepian (dekat) sungai; (2) Tapak permukiman pedalaman (jauh dari sungai). Dalam penelitian ini permukiman yang diteliti adalah permukiman daerah rawa di tepian sungai. Pola permukiman daerah rawa di tepian sungai secara umum bisa dikategorikan menjadi dua yaitu yang berorientasi ke jalan dan yang berorientasi ke sungai dengan masing-masing karakteristiknya (Lussetyowati, 2014). Perkampungan dengan orientasi ke jalan Jalan utama merupakan orientasi semua jalan setapak.

Bangunan juga mempunyai orientasi ke jalan. Bangunan-bangunan pada lapis belakang berdiri menyambung ke jalan dengan jalan setapak dari kayu (jerambah).

Pola perkampungan yang digunakan kebanyakan merupakan gabungan pola grid dengan pola linear. Ketergantungan pada sungai tidak terlalu besar terutama dalam hal transportasi. 2) Perkampungan dengan orientais ke sungai. Merupakan orientasi awal perkempungan di Palembang, karena dulunya sungai merupakan jalur transportasi utama.

Perkampungan dengan orientasi ke sungai mulai berubah dengan berkembangnya jalur transportasi ke darat dan sekarang perkampungan dengan model tersebut hanya tinggal di lapisan tepian sungai yang lebar saja.

Pada perkampungan jenis ini orientasi bangunan ke sungai dan biasanya di tiap unit lingkungan mempunyai dermaga kecil di depannya sebagai tempat tambatan perahu (Gambar 1).

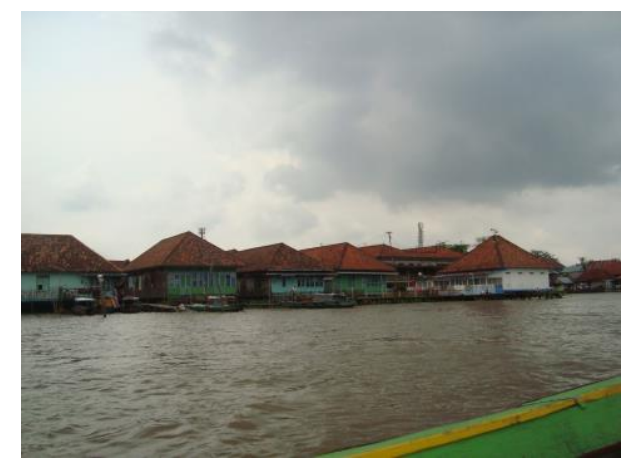

Gambar 1. Kondisi Permukiman Lahan basah di Tepi Sungai Musi

\section{Tipologi Bangunan}

Sebagian besar bangunan pada permukiman daerah rawa adalah bangunan rumah panggung. Bangunan panggung atau di atas tiang biasanya disebut rumah panggung merupakan rumah yang berdiri di atas tiang dan menggunakan tangga untuk mencapainya. Rumah ini bisa dibagi lagi menjadi dua macam yaitu rumah limas dan rumah gudang.

Rumah limas merupakan rumah yang bentuk atapnya seperti rumah joglo (mirip bangunan rumah Jawa) yang berdiri di atas tiang-tiang dan tiang-tiang tersebut berdiri di atas tanah dengan ketinggian tertentu. Ketinggian tiang ini biasanya diukur berdasarkan ketinggian air pasang tertinggi pada daerah tersebut, sehingga pada saat pasang air tertinggi pada musim-musim tertentu air tiak menggenangi rumah. Rumah limas ini dulunya merupakan rumah tinggal para bangsawan. Ciri khas rumah limas adalah terdapat perbedaan ketinggian lantai, hal ini ada hubungannya dengan hirarki ruang dan juga hirarki social yang berlaku pada masa itu. Pada bagian atap rumah terdapat ornemen yang bentuknya seperti mahkota.

Berbeda dengan rumah limas, maka rumah gudang ini biasanya ditinggali oleh orang kebanyakan atau para pedagang dan sering dilengkapi dengan gudang tempat penyimpanan barang dagangan. Bentuk atap rumah ini adalah perisai dan tidak menggunakan ornament pada atapnya. Selain itu tidak ada perbedaan ketinggian lantai, dan lantainya berbentuk rata. Rumah tipe gudang ini sampai sekarang maish banyak digunakan oleh penduduk Palembang dan bahkan banyak yang membangun rumah baru dengan tipe seperti ini, terutama pada daerah rawa.

\section{Pola Sirkulasi}

Pada perkampungan di atas rawa tepian sungai terdapat dua jalur sirkulasi utama yaitu jalur jalan dan jalur sungai. Di antara kedua jalur sirkulasi ini dihubungkan dengan jalanjalan kecil berupa jerambah.

Jalur jalan ini merupakan jalur pergerakan utama setelah berkembangnya transportasi darat. Jalan darat di daerah rawa ini merupakan rawa yang ditimbun dan kemudian diperkeras dengan asapal. Ketinggian timbunan biasanya diperhitungkan berdasarkan ketinggian pasang air tertinggi pada daerah tersebut. Daerah tepian jalan biasanya banyak digunakan sebagai tempat 
fasilitas umum seperti sekolah, masjid, kantor, puskesmas, toko, warung, dll. Selain itu pada bahu jalan atau tepian jalan yang ditimbun biasanya digunakan untuk parkir kendaraan roda empat atau becak. Hal ini disebabkan karena pada lapis belakang jalur jalan ini biasanya hanya bisa dilalui oleh pejalan kaki atau kendaraan roda dua, sehingga penduduk yang memiliki kendaraan roda empat biasanya memarkir kendaraannya di tepi jalan. Di sini diperlukan pengaturan tempat parkir di tepian jalan agar tidak mengganggu kelancaran lalu lintas di daerah tersebut.

$\begin{array}{clc}\begin{array}{c}\text { Sungai } \\ \text { transportasi }\end{array} & \begin{array}{l}\text { dulunya merupakan } \\ \text { utama, }\end{array} & \begin{array}{c}\text { jalur } \\ \text { tetapi }\end{array}\end{array}$
berkembangnya transportasi darat sungai menjadi jalur alternative terutama pada tepian sungai besar, sedang pada sungai-sungai kecil sudah tidak dimanfaatkan lagi sebagai jalur transportasi karena banyak terjadi pendangkalan. Pada tepian sungai banyak terdapat dermaga-dermaga (besar ataupun kecil) yang digunakan untuk tempat tambatan perahu sekaligus tempat turun naik penumpang.

Jalan lingkungan yang ada biasanya berupa jalan setapak dengan lebar antara 1-2 m berupa jalan di atas tiang yang disebut jerambah (Lussetyowati, 2012). Jerambah ini terbuat dari bahan kayu dengan tiang dan papanpapan yang bisa dilewati oleh pejalan kaki. Pada beberapa tempat bahan jerambah ini menggunakan beton bertulang dan bisa dilewati kendaraan roda dua. Daerah dengan kondisi jalan seperti ini meliputi area yang cukup luas dan menimbulkan beberapa masalah terutama pada saat terjadi kebakaran, mobil pemadam kebakaran tida bisa mencapai ke lokasi karena tidak ada jalan yang bisa dilaluinya.

\section{Pola Tata Bangunan}

Elemen place didalam permukiman tepian sungai mencerminkan bentuk kulturasi dalam kehidupan masyarakat tepian tumbuh dalam suatu bentuk tatanan yang ada (Bayu dan Susanto, 2010). Hal ini juga terlihat dalam bentukan pola tata bangunan di permukiman daerah rawa tepian sungai.

Pola tata bangunan yang digunakan menggunakan gabungan antara pola linear dan pola grid. Pola grid di sini tidak terlalu terlihat, karena grid yang tercipta tidak teratur. Hal ini disebabkan karena pertumbuhan permukiman di sini tidak mengikuti pola grid tertentu, tetapi lebih cenderung sporadis dan organis. Pola linear ini lebih disebabkan adanya material yang membentuk jalan-jalan setapak untuk menghubungkan rumah yang satu dengan yang lain yaitu dengan jerambah kayu. Keterbatasan material yang ada mempengaruhi bentukan jalan yang akhirnya juga mempengaruhi tata bangunan yang berorientasi ke jalan setapak tersebut.

Jarak antar bangunan sangat rapat dan menyebabkan kurang sehatnya lingkungan hunian tersebut. Hal ini disebabkan kolongkolong rumah menjadi tidak terkena sinar matahari dengan baik dan menjadi lembab, sehingga banyak nyamuk yang menghuni di kolong-kolong tersebut. Hal ini juga diperparah oleh cara hidup yang tidak sehat, mislanya membuang sampah atau limbah rumah tangga ke kolong rumah begitu saja.

\section{Ruang Terbuka}

Ruang terbuka pada permukiman daerah rawa berbeda dengan di darat. Ruang terbuka di sini meliputi jalur pergerakan (jalan, jerambah, sungai) dan ruang antara bangunan. Ruang terbuka yang menjadi ruang public terutama terletak pada areal yang bisa 'diinjak', artinya di sini adalah ruang-ruang yang bisa untuk 'bergerak'. Ruang-ruang ini berupa jalan (darat) ataupun jerambah (jalan setapak di atas tiang). Ruang terbuka yang lain adalah ruang-ruang antara bangunan berupa rawa-rawa yang pada saat musim pasang digenangi air dan pada saat musim kering menjadi 'daratan'. Untuk memenuhi kebutuhan akan ruang terbuka ini kadang-kadang penduduk berusaha 'memperlebar' daratan tersebut, dengan menambah pelataran dari papan yang disusun di atas tiang. Selain itu serambi rumah juga merupakan bagian penting dari rumah sebagai tempat bersosialisasi dengan tetangganya.

Ruang terbuka untuk area bermain anak secara spesifik tidak ada. Tetapi anak-anak mempunyai pola permainan sendiri yang sangat terkait dengan air seperti berperahu, berenang dan memancing atau mencari ikan. Di sini terlihat bahwa bagi anak-anak tempat bermain tidak pernah menjadi masalah, bagaimana dan di manapun tempatnya. Anak-anak pada permukiman daerah rawa mempunyai pola permainan gabungan antara darat dan air. Pada saat musim pasang mereka bermain di air dan pada saat musim surut dan daratan menjadi kering mereka bermain di darat. 


\section{KESIMPULAN}

Dari hasil penelitian didapatkan beberapa kesimpulan, yaitu:

1. Permukiman di daerah rawa mempunyai karakteristik yang unik, karena sebagian besar kegiatan penduduknya dilakukan di atas air atau daerah yang masih bisa diinjak.

2. Pola kegiatan sehari-hari penduduk di atas rawa tidak ada bedanya dengan penduduk di daratan, hanya saja dalam penggunaan ruangnya menyesuaikan dengan kondisi alam yang ada.

3. Pola perkampungannya bisa dibagi menjadi dua yaitu pola perkampungan dengan orientasi ke jalan dan perkampungan dengan orientasi ke sungai.

4. Pola-pola perkembangan permukiman daerah ini mempunyai ciri khas tersendiri, karena merupakan perkampungan yang tumbuh secara alamiah tanpa mengadakan perubahan yang berarti pada lingkungan alamnya (rawanya tidak ditimbun). Sementara itu kebutuhan orang akan ruang kota dalam permukiman secara umum sama, baik pada daerah rawa maupun darat. Dalam batas-batas tertentu kebutuhan ini bisa terakomodasi walaupun terjadi penyesuaian. Pola permukiman yang demikian ini menunjukkan kearifan lokal penduduk dalam mengelola daerah rawa tanpa menyebabkan gangguan terhadap lingkungan alam.

5. Pembentukan pola permukiman di lahan basah ini juga merupakan salah satu hasil lansekap budaya karena merupakan hasil dari proses sejarah yang kompleks dan mencerminkan keterkaitan dengan kehidupan sehari-hari penduduknya dnegan lingkungan alamnya.

\section{Daftar Pustaka}

Rapoport, Amos (1992) On Cultural Landscape, TDSR Volule III no II tahun 1992.

Antariksa (2011) Struktur Ruang Budaya Dalam Permukiman, Architecture Articles.

Yin, R. K. (2014) Studi Kasus, Desain dan Metode, PT Raja Grafindo Persada, Jakarta.
Robert R. Page, Cathy A.Gilbert \& Susan A. Dolan (1998) A Guide to Cultural Landscpae Report, Content, Process and Techniques. US Departement of Interiror National Park Service, Washington DC.

Lucy Shuker, Angela M Gurnell, Mike Raco (2008) Culture, indigenous knowledge system and sustainable development: A critical view of education in an African context, Urban Ecosystem Journal.

Doxiadis (1968) Ekistics: An Introduction To The Science Of Human Settlement, Hutchinson of London.

Dahliani (2012) Konsep Pengolahan Tapak Permukiman Di Lahan Rawa, Banjarmasin, Jurnal Lanting Journal Of Architecture.

Lussetyowati,T. (2014) Studi Perkembangan Permukiman Daerah Rawa di Kota Palembang. Prosiding Seminar Nasional Membangun Kota Berbasis Lokalitas, UNS Solo.

Lussetyowati,T. (2012) Penggunaan Ruang Publik Di Permukiman Tepian Sungai Musi Palembang. Prosiding Seminar Nasional Ruang Bersama Nusantara, Universitas Brawijaya, Malang.

Bayu, C. dan Susanto, A. (2010) Perubahan Pola Ruang Perkotaan Dalam Transformasi Sosial Budaya Masyarakat Tepian Sungai Kapuas Di Pontianak - Kalimantan Barat. Jurnal Ilmu Pengetahuan dan Rekayasa, Januari. 